OPEN ACCESS

Edited by:

Wei Xiao,

Yangtze University, China

Reviewed by:

Zhipeng Ma

Yanshan University, China

Yuanhua Xiao,

Zhengzhou University of Light

Industry, China

*Correspondence:

Ling Wang

tswling@126.com

Zhangxing $\mathrm{He}$

zxhe@ncst.edu.cn

Specialty section:

This article was submitted to

Electrochemistry,

a section of the journal

Frontiers in Chemistry

Received: 06 November 2020 Accepted: 07 December 2020

Published: 14 January 2021

Citation:

Wu S, Lv X, Ge Z, Wang L, Dai L and He $Z$ (2021) Thiourea-Grafted Graphite Felts as Positive Electrode for Vanadium Redox Flow Battery.

Front. Chem. 8:626490

doi: 10.3389/fchem.2020.626490

\section{Thiourea-Grafted Graphite Felts as Positive Electrode for Vanadium Redox Flow Battery}

\author{
Shangzhuo Wu, Xin Lv, Zhijun Ge, Ling Wang*, Lei Dai and Zhangxing He* \\ School of Chemical Engineering, North China University of Science and Technology, Tangshan, China
}

In this paper, thiourea was successfully grafted onto the surface of acid preprocessed graphite felts [sulfuric acid-treated graphite felt (SA-GFs)] by thiol-carboxylic acid esterification. The thiourea-grafted graphite felts (TG-GFs) were investigated as the positive electrode for vanadium redox flow battery (VRFB). X-ray photoelectron spectroscopy results suggested that thiourea was grafted into the surface of graphite felts. The cyclic voltammetry showed that the peak potential separation decreased by $0.2 \mathrm{~V}$, and peak currents were greatly enhanced on TG-GF electrode compared with SA-GF electrode, implying improved electro-catalytic activity and reversibility of TG-GF electrode toward $\mathrm{VO}^{2+} \mathrm{NO}_{2}^{+}$redox reaction. The initial capacity of TG-GF-based cell reached $55.6 \mathrm{~mA} \mathrm{~h}$ at $100 \mathrm{~mA} \mathrm{~cm}{ }^{-2}, 22.6 \mathrm{~mA}$ h larger than that of SA-GF-based cell. The voltage and energy efficiency for TG-GF-based cell increased by $4.9 \%$ and $4.4 \%$ compared with those of SA-GF-based cell at $100 \mathrm{~mA} \mathrm{~cm}^{-2}$, respectively.

Keywords: vanadium redox flow battery, graphite felts, thiourea, grafted, energy storage

\section{INTRODUCTION}

Vanadium redox flow battery (VRFB) as energy storage system has caused more and more attention because VRFB displays some advanced characteristics, such as long cycle life, high energy efficiency (EE), and excellent electrochemical reversibility (Bhushan et al., 2019; Li et al., 2019; Xiang and Daoud, 2019; He et al., 2020; Lv et al., 2020). The electrodes play a central role where redox reactions occur (Ding et al., 2018; Ye et al., 2018). Although the commercial graphite felts can be used as electrode materials for VRFB, the electrochemical activity is not enough for practical application (He et al., 2015).

The introduction of functional groups is one of the effective surface functional treatments to improve the electrochemical properties of the graphite felts. Among the functional groups, oxygen-containing groups, such as $-\mathrm{COOH},-\mathrm{OH}$, and $\mathrm{C}=\mathrm{O}$, have been widely studied by various methods including heat treatment (Zhang et al., 2020), acid treatment (Sun and Skyllas-Kazacos, 2010), electrochemical oxidation (Xiao-Gang et al., 2007), and microwave treatment (Wu et al., 2014). In addition, the nitrogen-containing groups also have been reported to be active toward vanadium redox reactions. Tao et al. (2012) reported a hydrothermal ammoniated treatment for graphite felt used as the positive electrode for VRFB. The introduction of the polar nitrogenous groups can facilitate the charge transfer rate between electrode and vanadium ions. He et al. (2013) added two organic additives in positive electrolyte, which provided $-\mathrm{NH}_{2}$ group on the surface of the graphite felt and could be employed as active sites for vanadium ion reactions. Recently, Lee et al. (2015) reported that the supercapacitor performance based on thiourea $\left(\mathrm{NH}_{2} \mathrm{CSNH}_{2}\right)$-grafted 
graphene could be greatly improved due to introducing the amine and sulfur functional groups into graphene. In addition, the electrocatalytic properties of multi-walled carbon nanotubes toward the $\mathrm{VO}^{2+} / \mathrm{VO}_{2}^{+}$redox couple were also improved by surface functional treatments using thiourea as nitrogen and sulfur sources (Li et al., 2017).
In this work, we report a novel, simple, and mild method for in situ functionalizing graphite felt electrode by grafting thiourea for VRFB. The $-\mathrm{NH}_{2}$ and $\mathrm{C}-\mathrm{S}$ functional groups were successfully introduced onto the surface of graphite felts. The VRFB using the thiourea-grafted graphite felt as positive electrode showed larger discharge capacity (DC) and EE.

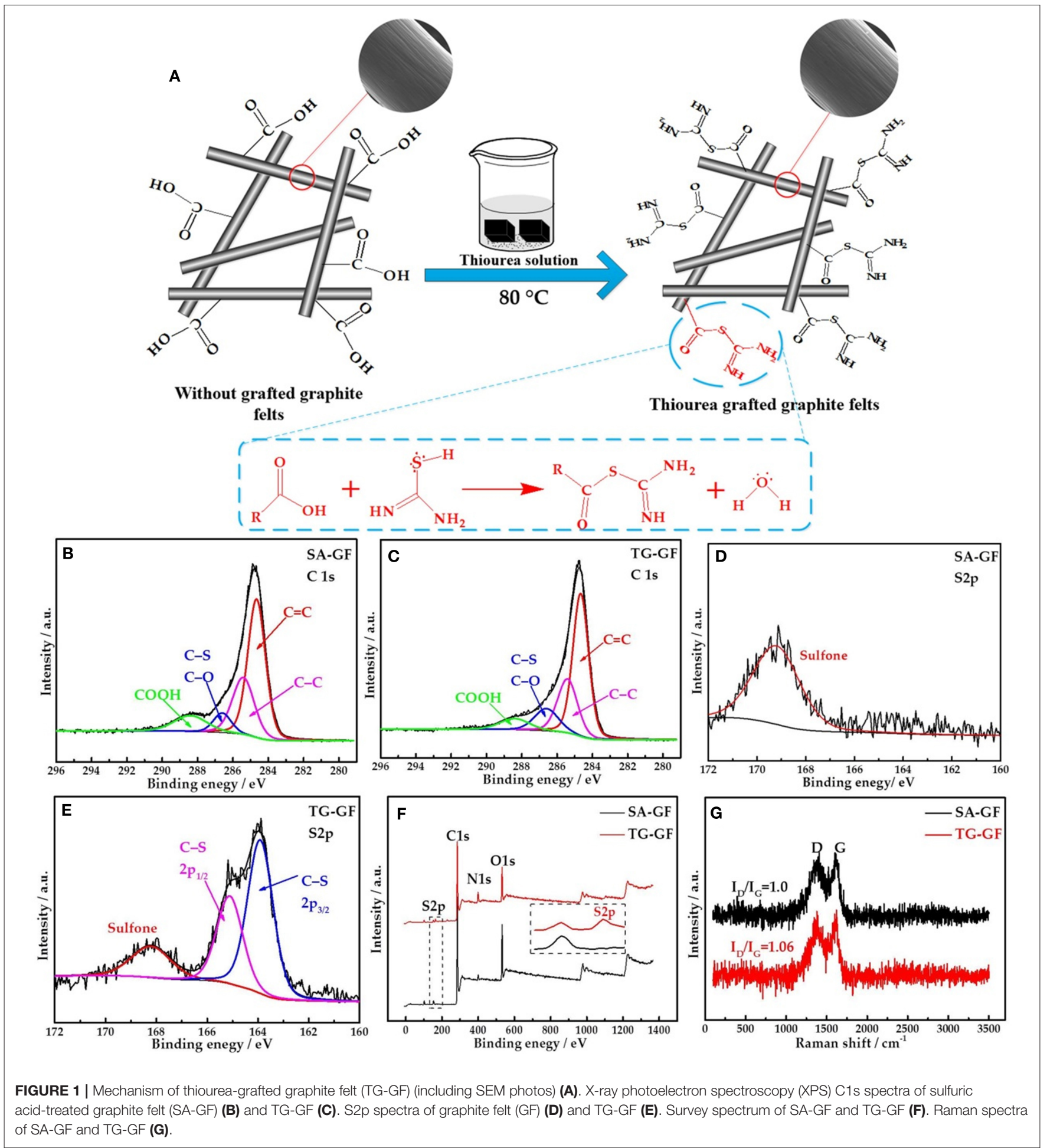




\section{EXPERIMENT}

\section{Preparation of the Electrode}

Polyacrylonitrile (PAN)-based graphite felts (GFs) (thickness: $6 \mathrm{~mm}$; Beijing Jinglong Carbon Technology Co., Ltd.) were pretreated with $98 \%$ sulfuric acid at room temperature for $24 \mathrm{~h}$. In order to obtain thiourea-grafted graphite felts, the sulfuric acidtreated graphite felts (SA-GFs) were placed in a beaker containing $30 \mathrm{ml}$ of $150 \mathrm{mg} \mathrm{ml}^{-1}$ thiourea solution, and then the beaker was kept in a water bath at $80^{\circ} \mathrm{C}$ for $10 \mathrm{~h}$ (Lee et al., 2015).

\section{Characterization}

Morphology of samples was characterized by scanning electron microscopy (SEM, S-4800, Hitachi, Japan). X-ray photoelectron spectroscopy (XPS) was carried out (K-Alpha 1063, Thermo Fisher Scientific, UK) for characterization of the surface chemistry of samples. Raman spectra were recorded on a laser Raman spectrometer (Thermo Electron DXR, USA).

\section{Electrochemical Measurements}

The electrochemical measurements [cyclic voltammogram (CV) and electrochemical impedance spectroscopy (EIS)] of the prepared electrode (area: $1 \mathrm{~cm}^{-2}$ ) were carried out on IM6e Zennium electrochemical workstation (Zahner Scientific Instruments, Germany) using Pt electrode and saturated calomel electrode (SCE) as the counter and reference electrodes, respectively. The electrolyte consisted of $0.1 \mathrm{M} \mathrm{VOSO}_{4}$ and $3 \mathrm{M}$ $\mathrm{H}_{2} \mathrm{SO}_{4}$. The scan rate of $\mathrm{CV}$ test was $1 \mathrm{mV} \mathrm{s}^{-1}$. The frequency range of EIS was $10^{-2}-10^{6} \mathrm{~Hz}$.

The charge-discharge performance for TG-GF electrode was assessed in a static cell using CT2001A (LAND, Wuhan) battery test system. The cells were assembled using TG-GF and SAGF $\left(3 \times 3 \mathrm{~cm}^{2}\right)$ as positive electrode, SA-GF as corresponding negative electrode, and perfluorinated ion-exchange membrane as separator in $1.2 \mathrm{M} \mathrm{V}(\mathrm{III}) / \mathrm{V}(\mathrm{IV})+3 \mathrm{M} \mathrm{H}_{2} \mathrm{SO}_{4}$ electrolyte.

\section{RESULTS AND DISCUSSION}

As shown in Figure 1A, thione $(C=S)$ in thiourea exists a resonance structure thiol (C-S-H). The amine groups connected with the $\mathrm{C}-\mathrm{S}-\mathrm{H}$ can react with carboxylic acid $(\mathrm{COOH})$ on the graphite felts via thiol-carboxylic acid esterification (Lee et al., 2015). SEM images for SA-GF and TG-GF (Figure 1A) show no obvious change of morphology. Figures 1B,C show the C1s high-resolution XPS spectra of SA-GF and TG-GF. Two samples contain $\mathrm{C}=\mathrm{C}(284.4 \mathrm{eV}), \mathrm{C}-\mathrm{C}(285.4 \mathrm{eV}), \mathrm{C}-\mathrm{S} / \mathrm{C}-\mathrm{O}$ $(286.5 \mathrm{eV})$, and $\mathrm{COOH}(288.6 \mathrm{eV})$ functional groups (Liu et al., 2015; Kabtamu et al., 2017). The peak at $286.5 \mathrm{eV}$ represents carbon in SA-GF bound to one oxygen or sulfur (e.g., C-O, C-S) (Gattrell et al., 2006). XPS spectra for S2p shown in Figures 1D,E indicate that TG-GF sample exhibits $\mathrm{S} 2 \mathrm{p}_{3 / 2}$ and $\mathrm{S} 2 \mathrm{p}_{1 / 2}$ signals at 163.9 and $165.1 \mathrm{eV}$, respectively, as well as a trace peak at $168.2 \mathrm{eV}$ (Baker et al., 2004; Huang et al., 2014). As shown in Table 1, compared with SA-GF, TG-GF has more C-S groups but lower $\mathrm{COOH}$ functional groups, which is attributed to the reaction between the carboxyl groups on SA-GF surface and the grafting of the amine and sulfur functional groups on thiourea, accompanied by the introduction of $\mathrm{C}-\mathrm{S}$ and $-\mathrm{NH}_{2}$ groups on the surface of SA-GF. The $\mathrm{O}$ atomic percentage of TG-GF decreases to $12.8 \%$ from $24.1 \%$ after grafting thiourea group onto SA-GF. Meanwhile, $\mathrm{S}$ atomic percentage of TG-GF increases to $1.8 \%$ from $1.1 \%$, and $\mathrm{N}$ atomic percentage increases to $8.1 \%$ from $5.9 \%$. The trace peak at $168.2 \mathrm{eV}$ is ascribed to sulfone species (Huang et al., 2014; Lee et al., 2015). XPS full spectra of SA-GF and TG-GF (Figure 1F) show a very clear S2p signal appearance for TG-GF, while for SA-GF, without S2p signal. Figure 1G shows Raman spectra of both samples. SA-GF and TG-GF samples give similar Raman scattering patterns with peaks at 1,380 ( $\mathrm{D}$ band) and 1,600 $\mathrm{cm}^{-1}$ (G band). The intensity ratio of $\mathrm{D}$ to $\mathrm{G}$ band $\left(I_{D} / I_{G}\right)$ that represents the extent of defects in carbon materials is different. The increase of $I_{D} / I_{G}$ value from 1.00 for SA-GF to 1.06 for TGGF means the decrease in the ordered graphite crystal structure after SA-GF grafting thiourea (Lee et al., 2015).

CV curves of all electrodes (Figure 2A) appear two peaks, which correspond to oxidation and reduction reactions of $\mathrm{VO}^{2+} / \mathrm{VO}_{2}^{+}$couple. Compared with SA-GF, the redox peak potential separation of TG-GF dramatically decreases from 0.686 to $0.483 \mathrm{~V}$. The peak currents are in the order of TG-GF $>\mathrm{SA}-\mathrm{GF}>\mathrm{GF}$, showing that sulfuric acid pretreatment can slightly improve the performance of GF. However, thiourea grafting can greatly enhance the electrochemical activity and reversibility toward the $\mathrm{VO}^{2+} / \mathrm{VO}_{2}^{+}$redox reaction. The little peak appearing at $1.3-1.5 \mathrm{~V}$ for TG-GF is ascribed to the slight oxygen evolution reaction.

Figure 2B shows Nyquist plots of three electrodes. A semicircle and a straight line are observed at high and low frequencies, respectively. $R_{\mathrm{S}}$ is attributed to the resistance of electrolyte and electrode. $R_{c t}$ represents Faradaic interfacial charge-transfer resistance. The constant-phase element $(C P E)$ is attributed to the double-layer capacitance, and $W$ is Warburg impedance ( $\mathrm{Li}$ et al., 2017). According to fitting results, the $R s$ values for GF, SA-GF, and TG-GF were almost equivalent. $R_{c t}$ of GF $(25.8 \Omega)$ is higher than that of other electrodes, suggesting poorer electrochemical activity of GF. The decrease of $R_{c t}$ value from $15.50 \Omega$ for SA-GF to $10.25 \Omega$ for TG-GF indicates that grafting thiourea onto SA-GF can reduce the electrochemical polarization.

Figure $3 \mathbf{A}$ shows the charge-discharge curves of the cells at $30 \mathrm{~mA} \mathrm{~cm}{ }^{-2}$. Compared with SA-GF-based cell, TG-GF-based cell delivers longer charge-discharge time, lower charge voltage, and higher discharge voltage, which leads to the improvement of the DC and EE. Figure 3B presents the DC dependence on cycle number at $30 \mathrm{~mA} \mathrm{~cm}^{-2}$. TG-GF-based cell shows higher DC than that of SA-GF-based cell. For example, in the first cycle, DC of TG-GF-based cell is $81.2 \mathrm{~mA} \mathrm{~h}, 18.7 \mathrm{~mA}$ h larger than that of SAGF-based cell. Meanwhile, the $87.4 \%$ DC retention and $87.3 \%$ average EE for TG-GF-based cell are 6.0 and 2.5\% larger than those of SA-GF-based cell, respectively (Figure 3C).

Figure 3D presents the DC of both cells at different current densities. The DCs of TG-GF-based cell are improved significantly at different current densities. For example, DC of TG-GF-based cell is $55.6 \mathrm{~mA} \mathrm{~h}$ at $100 \mathrm{~mA} \mathrm{~cm}^{-2}$, which is much larger than that of SA-GF-based cell $(22.6 \mathrm{~mA} \mathrm{~h})$. Figures 3E,F 
TABLE 1 | Elemental composition and chemical composition of functional groups based on C1s and S2p XPS spectra.

\begin{tabular}{|c|c|c|c|c|c|c|c|c|c|c|}
\hline \multirow[t]{2}{*}{ Samples } & \multicolumn{4}{|c|}{$\begin{array}{c}\text { Elemental } \\
\text { composition (\%) }\end{array}$} & \multicolumn{4}{|c|}{$\begin{array}{c}\text { C1s peak } \\
\text { deconvolution (\%) }\end{array}$} & \multicolumn{2}{|c|}{$\begin{array}{c}\text { S2p peak } \\
\text { deconvolution (\%) }\end{array}$} \\
\hline & C & $\mathbf{N}$ & 0 & $\mathbf{s}$ & $C=C$ & C-C & C-O/C-S & $\mathrm{COOH}$ & $\mathrm{s} 2 \mathrm{p}_{3 / 2}$ & $\mathbf{s} 2 p_{1 / 2}$ \\
\hline SA-GF & 68.92 & 5.89 & 24.11 & 1.08 & 55.55 & 23.49 & 11.52 & 9.43 & - & - \\
\hline TG-GF & 77.22 & 8.1 & 12.83 & 1.85 & 54.33 & 23.56 & 15.75 & 6.35 & 52.68 & 30.59 \\
\hline
\end{tabular}

SA-GF, sulfuric acid-treated graphite felt; TG-GF, thiourea-grafted graphite felt; XPS, X-ray photoelectron spectroscopy.
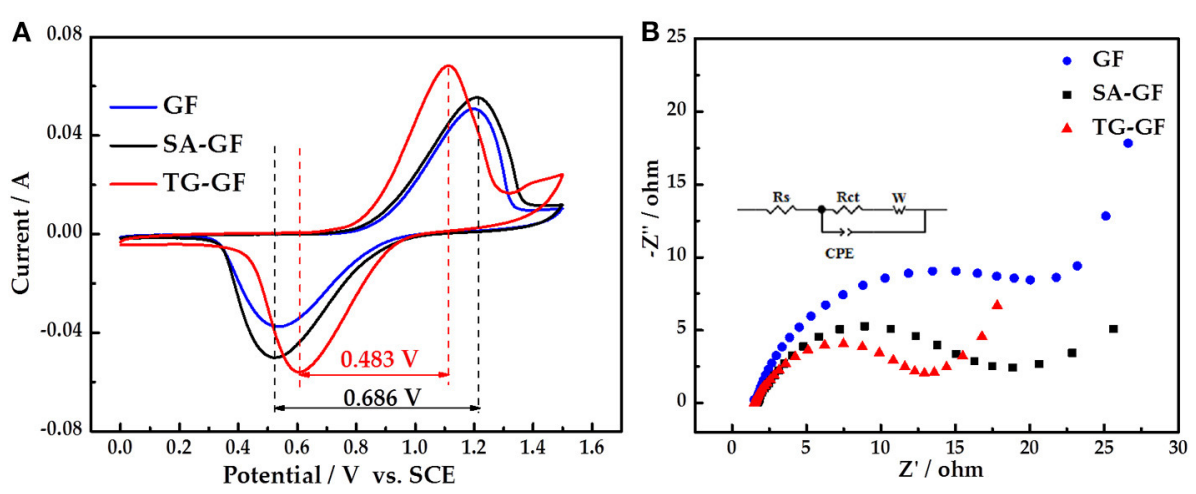

FIGURE 2 | Cyclic voltammogram (CV) (A) and Nyquist plot (B) curves of graphite felt (GF), sulfuric acid-treated graphite felt (SA-GF), and thiourea-grafted graphite felt (TG-GF) in $0.1 \mathrm{M} \mathrm{VOSO}_{4}+3 \mathrm{M} \mathrm{H}_{2} \mathrm{SO}_{4}$ electrolyte.
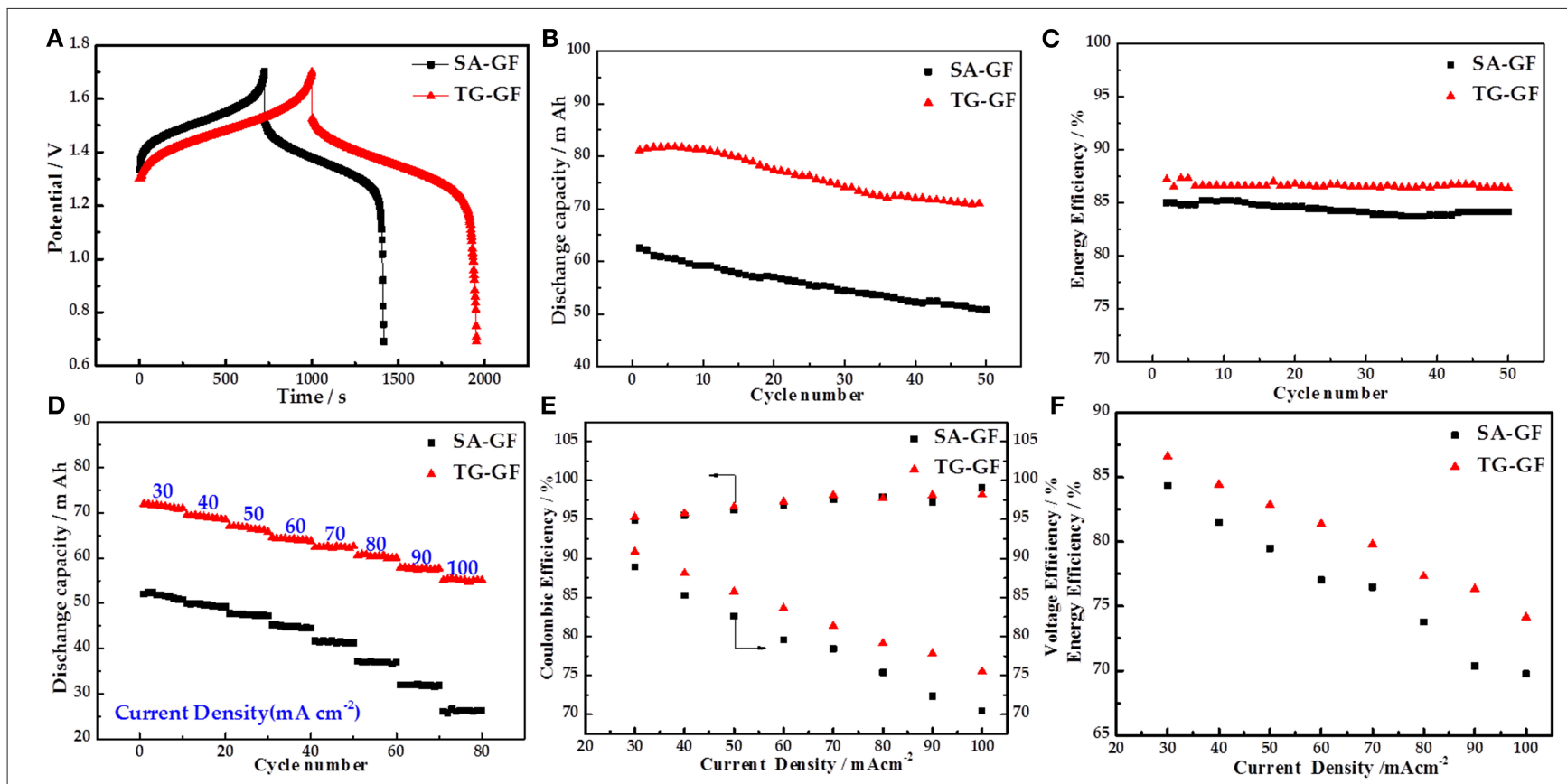

FIGURE 3 | Electrochemical performances of vanadium redox flow battery (VRFB) cells with sulfuric acid-treated graphite felt (SA-GF) and thiourea-grafted graphite felt (TG-GF): (A) charge-discharge curves, (B) discharge capacity, and (C) energy efficiency (EE) of VRFB at the current density of $30 \mathrm{~mA} \mathrm{~cm}{ }^{-2}$; (D) discharge capacity, (E) coulombic efficiency (CE), voltage efficiency (VE), and (F) EE of VRFB at the different current densities.

show the coulombic efficiency (CE), voltage efficiency (VE), and $\mathrm{EE}$ of the cells at different current densities. The CE values for two cells are almost the same, while the VE and EE of TG-GFbased cell are much higher than those of SA-GF-based cell at all current densities, especially at high current density. For example, the VE and EE of TG-GF-based cell are 75.5 and $74.1 \%$ at $100 \mathrm{~mA}$ $\mathrm{cm}^{-2}$, which are 4.9 and $4.4 \%$ higher than those of SA-GF-based cell, respectively. 


\section{CONCLUSIONS}

In order to improve the performance of the electrode, thiourea was grafted onto the surface of SA-GF by thiol-carboxylic acid esterification. Both electrochemical activity and reversibility of the modified electrode toward $\mathrm{VO}^{2+} / \mathrm{VO}_{2}^{+}$redox reaction are improved. Compared with SA-GF-based cell, the cell using TGGF electrode displays higher DC and VE due to a lower charge transfer resistance, particularly at a high current density.

\section{DATA AVAILABILITY STATEMENT}

The original contributions presented in the study are included in the article/supplementary material, further inquiries can be directed to the corresponding author/s.

\section{REFERENCES}

Baker, W. S., Long, J. W., Stroud, R. M., and Rolison, D. R. (2004). Sulfurfunctionalized carbon aerogels: a new approach for loading high-surface-area electrode nanoarchitectures with precious metal catalysts. J. Non Cryst. Solids 350, 80-87. doi: 10.1016/j.jnoncrysol.2004.07.088

Bhushan, M., Kumar, S., Singh, A. K., and Shahi, V. K. (2019). High-performance membrane for vanadium redox flow batteries: cross-linked poly(ether ether ketone) grafted with sulfonic acid groups via the spacer. J. Membr. Sci. 583, 1-8. doi: 10.1016/j.memsci.2019.04.028

Ding, M., Ling, X., Yuan, D., Cheng, Y. H., Wu, C., Chao, Z. S., et al. (2018). SPEEK membrane of ultrahigh stability enhanced by functionalized carbon nanotubes for vanadium redox flow battery. Front. Chem. 6:286. doi: $10.3389 /$ fchem.2018.00286

Gattrell, M., Qian, J., Stewart, C., Graham, P., and MacDougall, B. (2006). The electrochemical reduction of $\mathrm{VO} 2+$ in acidic solution at high overpotentials. Electrochim. Acta 51, 395-407. doi: 10.1016/j.electacta.2005.05.001

He, Z., Cheng, G., Jiang, Y., Li, Y., Zhu, J., Meng, W., et al. (2020). Novel 2D porous carbon nanosheet derived from biomass: ultrahigh porosity and excellent performances toward $\mathrm{V}^{2+} / \mathrm{V}^{3+}$ redox reaction for vanadium redox flow battery. Int. J. Hydrog. Energy 45, 3959-3970. doi: 10.1016/j.ijhydene.2019.12.045

He, Z., Dai, L., Liu, S., Wang, L., and Li, C. (2015). $\mathrm{Mn}_{3} \mathrm{O}_{4}$ anchored on carbon nanotubes as an electrode reaction catalyst of $\mathrm{V}(\mathrm{IV}) / \mathrm{V}(\mathrm{V})$ couple for vanadium redox flow batteries. Electrochim. Acta 176, 1434-1440. doi: 10.1016/j.electacta.2015.07.067

He, Z. X., Liu, J. L., Han, H. G., Chen, Y., Zhou, Z., Zheng, S. J., et al. (2013). Effects of organic additives containing $-\mathrm{NH} 2$ and $-\mathrm{SO} 3 \mathrm{H}$ on electrochemical properties of vanadium redox flow battery. Electrochim. Acta 106, 556-562. doi: 10.1016/j.electacta.2013.05.086

Huang, Y., Candelaria, S. L., Li, Y., Li, Z., Tian, J., Zhang, L., et al. (2014). Sulfurized activated carbon for high energy density supercapacitors. J. Power Sources 252, 90-97. doi: 10.1016/j.jpowsour.2013.12.004

Kabtamu, D. M., Chen, J. Y., Chang, Y. C., and Wang, C. H. (2017). Wateractivated graphite felt as a high-performance electrode for vanadium redox flow batteries. J. Power Sources 341, 270-279. doi: 10.1016/j.jpowsour.2016.12.004

Lee, W. S. V., Leng, M., Li, M., Huang, X. L., and Xue, J. M. (2015). Sulphurfunctionalized graphene towards high performance supercapacitor. Nano Energy 12, 250-257. doi: 10.1016/j.nanoen.2014.12.030

Li, C. C., Xie, B. S., Chen, J., He, J. J., and He, Z. X. (2017). Enhancement of nitrogen and sulfur co-doping on the electrocatalytic properties of carbon nanotubes for $\mathrm{VO}^{2+} / \mathrm{VO}_{2}^{+}$redox reaction. RSC Adv. 7, 13184-13190. doi: 10.1039/C6RA27734A

Li, Q., Liu, J., Bai, A., Li, P., Li, J., Zhang, X., et al. (2019). Preparation of a nitrogen-doped reduced graphene oxide-modified graphite felt electrode for $\mathrm{VO}^{2+} / \mathrm{VO}_{2}^{+}$reaction by freeze-drying and pyrolysis method. J. Chem. 2019, 1-9. doi: $10.1155 / 2019 / 8958946$

\section{AUTHOR CONTRIBUTIONS}

SW is mainly responsible for experimental operations and drafting paper. XL is mainly responsible for the collecting and processing experimental data. ZG is mainly responsible for collecting information and drafting paper. LW is mainly responsible for designing the experiment and the paper guidance. LD is mainly responsible for reviewing the final manuscript for publication. $\mathrm{ZH}$ is mainly responsible for making important modifications to the manuscript.

\section{FUNDING}

This work was financially supported by the Natural Science Foundation of China (51872090, 51772097).

Liu, T., Li, X., Nie, H., Xu, C., and Zhang, H. (2015). Investigation on the effect of catalyst on the electrochemical performance of carbon felt and graphite felt for vanadium flow batteries. J. Power Sources 286, 73-81. doi: 10.1016/j.jpowsour.2015.03.148

Lv, Y., Li, Y., Han, C., Chen, J., He, Z., Zhu, J., et al. (2020). Application of porous biomass carbon materials in vanadium redox flow battery. J. Colloid Interface Sci. 566, 434-443. doi: 10.1016/j.jcis.2020.01.118

Sun, B. T., and Skyllas-Kazacos, M. (2010). Chemical modification of graphite electrode materials for vanadium redox flow battery application-part II. Acid treatments. Electrochim. Acta 37, 1253-1260. doi: 10.1016/0013-4686(92)85064-R

Tao, W., Huang, K., Liu, S., Zhuang, S., Dong, F., Sha, L., et al. (2012). Hydrothermal ammoniated treatment of PAN-graphite felt for vanadium redox flow battery. J. Solid State Electrochem. 16, 579-585. doi: 10.1007/s10008-011-1383-y

Wu, X., Xu, H., Xu, P., Yang, S., Lu, L., Shi, J., et al. (2014). Microwavetreated graphite felt as the positive electrode for all-vanadium redox flow battery. J. Power Sources 263, 104-109. doi: 10.1016/j.jpowsour.2014. 04.035

Xiang, Y., and Daoud, W. A. (2019). Binary $\mathrm{NiCoO}_{2}$-modified graphite felt as an advanced positive electrode for vanadium redox flow batteries. J. Mater. Chem. A 7, 5589-5600. doi: 10.1039/C8TA09650C

Xiao-Gang, L. I., Huang, K. L., Liu, S. Q., Tan, N., and Chen, L. Q. (2007). Characteristics of graphite felt electrode electrochemically oxidized for vanadium redox battery application. Transact. Nonferrous Metals Soc. China 17, 195-199. doi: 10.1016/S1003-6326(07) 60071-5

Ye, J. Y., Lou, X. C., Wu, C., Wu, S. J., Ding, M., Sun, L. D., et al. (2018). Ion selectivity and stability enhancement of SPEEK/Lignin membrane for vanadium redox flow battery: the degree of sulfonation effect. Front. Chem. 6:549. doi: 10.3389/fchem.2018.00549

Zhang, R., Li, K., Ren, S., Chen, J., Feng, X., Jiang, Y., et al. (2020). Sb-doped $\mathrm{SnO}_{2}$ nanoparticle-modified carbon paper as a superior electrode for a vanadium redox flow battery. Appl. Surf. Sci. 526:146685. doi: 10.1016/j.apsusc.2020.146685

Conflict of Interest: The authors declare that the research was conducted in the absence of any commercial or financial relationships that could be construed as a potential conflict of interest.

Copyright (c) $2021 \mathrm{Wu}, \mathrm{Lv}, \mathrm{Ge}$, Wang, Dai and He. This is an open-access article distributed under the terms of the Creative Commons Attribution License (CC BY). The use, distribution or reproduction in other forums is permitted, provided the original author(s) and the copyright owner(s) are credited and that the original publication in this journal is cited, in accordance with accepted academic practice. No use, distribution or reproduction is permitted which does not comply with these terms. 